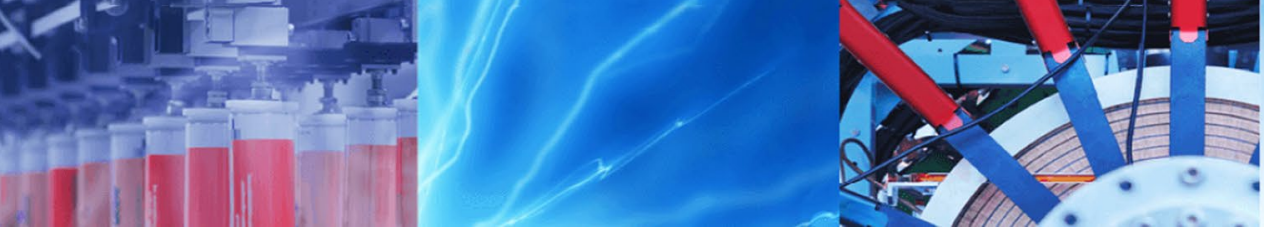

Research Article

\title{
Biodiesel from Saccharomyces cerevisiae: fuel property analysis and comparative economics
}

\author{
Mayur Mausoom Phukan ${ }^{1} \cdot$ Plaban Bora $^{2} \cdot$ Krishna Gogoi $^{3} \cdot$ Bolin Kumar Konwar $^{3}$
}

(c) Springer Nature Switzerland AG 2019

\begin{abstract}
The depletion of exhaustible underground petroleum resources has put the present civilization at stake, thereby warranting intense research on non-exhaustible fuel. With this energy crisis hitting the block, microorganisms such as yeasts are gaining wider importance as potential biofuel candidates. An indigenous yeast strain Saccharomyces cerevisiae isolated from laboratory-scale brewing was investigated for biodiesel production. Biodiesel was produced by in situ transesterification approach using 1,1,3,3-tetramethylguanidine as the catalyst. The fuel properties such as viscosity, density, calorific value and cetane number (CN) were determined to assess the fuel quality of $S$. cerevisiae biodiesel. Additionally, the investigation also focuses on theoretical studies considering the yeast de-oiled cake (low-value biomass refuse). Fatty acid methyl ester analysis revealed that biodiesel was primarily composed of tricosylic acid (C23:0, 28.71\%), palmitoleic acid (C16:1, 28.96\%) and oleic acid (C18:1, 18.13\%). Eicosapentaenoic acid (C20:5, 2.01\%), one of the most commonly known polyunsaturated fatty acid, was present in the yeast strain. The $\mathrm{CN}$ of yeast biodiesel was 71.58 , which was much higher than petro-diesel. The theoretical findings suggest the competitiveness of yeast biomass conversion technologies with petroleum refining process economics. The overall study warrants the feasibility of co-production of biodiesel from S. cerevisiae and cracked biofuel products (from S. cerevisiae de-oiled cake) under the aegis of biorefining applications.
\end{abstract}

Keywords Yeast $\cdot$ Saccharomyces cerevisiae $\cdot$ Biodiesel $\cdot$ Biorefinery $\cdot$ Comparative economics

\section{Introduction}

The depletion of exhaustible geological reservoirs has created a worldwide concern and consequently has spiked up interest in alternative fuels. Production of biofuels from renewable carbon neutral feedstock has long been a research goal for future replacement of conventional petro-fuels. Although numerous terrestrial energy crops have been investigated in this regard, the conundrum of the food versus fuel debate, limited geographical availability, higher processing costs and slow growth rate impedes their commercialization [1-3]. A cost-effective approach much conducive to improving the process economics of biofuel production may well be addressed by targeting oleaginous microorganisms such as microalgae, yeasts, fungi and bacteria.

Oleaginous microbes are an attractive alternative to higher plants for lipid production since their production does not require agricultural land, thereby avoiding displacement of food production [4, 5]. Furthermore, these microorganisms have short life cycles, require less labor inputs and are less susceptible to environmental variations

Electronic supplementary material The online version of this article (https://doi.org/10.1007/s42452-019-0159-3) contains supplementary material, which is available to authorized users.

Mayur Mausoom Phukan, mayur_101@yahoo.com | 'Department of Forest Science, School of Science, Nagaland University, Lumami, Zunheboto, Nagaland 798627, India. ${ }^{2}$ Department of Energy Engineering, Assam Science and Technology University, Guwahati, Assam 781013, India. ${ }^{3}$ Department of Molecular Biology and Biotechnology, School of Science, Tezpur University, Tezpur, Assam 784028, India. 
which further acquiesces their candidature as an ideal bioenergy feedstock. Among all these microorganisms today much of the scientific attention is focused on microalgae. Microalgae have been studied extensively on account of their various potential advantages for biofuel production when compared to terrestrial energy crops. They have been hypothesized to have tremendous theoretical potential as a renewable fuel source $[6,7]$. The most prominent renewable biofuels from microalgae are methane produced by anaerobic digestion of algal biomass [8-10], biodiesel from microalgal oil [11-18], photobiologically produced biohydrogen [19-22], bioethanol [23] and pyrolytic bio-oil [24-27]. The production of renewable biofuels from algae is undeniably of considerable scientific interest; however, substantial technical barriers presently foil their commercial utilization. These include the scarcity of suitable land given the current levels of productivity, lack of adequate photosynthetically active radiation and the prohibitive costs of delivering supplementary light, fertilizer, controlling temperature and protection against invasive non-lipid-producing species [28-33].

Considering these lacunas in microalgae, yeasts may be a potentially attractive biofuel option. Oleaginous yeasts are considered as a promising alternative lipid source for biodiesel fuel production [34]. Yeasts offer credible candidature for biodiesel production owing to their unicellular high growth rate, short life cycle, easy scale-up and rapid lipid-accumulating ability in discrete lipid bodies [35, 36]. Furthermore, they are also capable of utilizing inexpensive fermentation media such as nutritional residues from agriculture and industry [37-39]. Several species of yeasts like Rhodosporidium toruloides, Cryptococcus curvatus, Lipomyces starkeyi and Yarrowia lipolytica accumulate more than $20 \%$ of lipids of their dry cell weight [40-44]. Oleaginous yeast species are highly productive on a per cell basis, with lipid yields of up to $65 \%$ dry weight and biomass yields of 10-100 g/L within 3-7 days [45]. Besides, majority of the yeast lipids are comprised of long-chain fatty acids which are comparable to conventional vegetable oils used in biodiesel production [46]. Application of yeasts such as Saccharomyces cerevisiae strain for alcoholic fermentation has also been reported in a recent investigation on bioethanol and biogas co-production by an integrated biorefinery approach using the green macroalgae Chaetomorpha linum [47]. Regardless of having tremendous biofuel potential, there is paucity of scientific literature pertaining to yeast-based biodiesel when compared to microalgae. As such, we attempted to investigate the feasibility of biofuel production from yeast using our laboratory strain S. cerevisiae 0 A03.

This research aims to highlight the feasibility of biodiesel production from an indigenously isolated yeast strain S. cerevisiae 0A03 isolated from laboratory-scale brewing. Relevant fuel properties such as viscosity, density, calorific value and cetane number (CN) were determined to assess the fuel quality. Further, a theoretical approach based on a previous study [6] has been discussed to study the competitiveness of yeast biomass with current petroleum prices.

\section{Materials and methods}

\subsection{Isolation, purification, growth medium and culture conditions}

Yeast isolation was done from the starter culture cake used by the Ahom community, Assam, India, for preparation of rice beer. The starter culture cake was ground into fine powder. One gram of powder was homogenized in $5 \mathrm{~mL}$ sterile distilled water and serially diluted to $10^{-5}$ dilutions with Millipore water. Fifty microliters of aliquot from each of the dilutions was spread on YM agar plates (yeast extract $3 \mathrm{~g} / \mathrm{L}$, malt extract $3 \mathrm{~g} / \mathrm{L}$, peptone $5 \mathrm{~g} / \mathrm{L}$, glucose $10 \mathrm{~g} / \mathrm{L}$, agar $18 \mathrm{~g} / \mathrm{L}$ and $\mathrm{pH}$ 6.6). The plates were incubated at $25^{\circ} \mathrm{C}$ for $48 \mathrm{~h}$. The growing yeast colonies were divided on the basis of their morphological characteristics. Pure cultures were obtained from the distinct single colonies by quadrant streaking. The isolated strains were maintained in $20 \%$ glycerol at $-20^{\circ} \mathrm{C}$. Among the different isolates obtained, the fastest and dominantly growing isolate was used for the present investigation. For further experimentation, the isolated pure colonies were maintained at $28^{\circ} \mathrm{C}$ for $48 \mathrm{~h}$ in YM culture media (in triplicate in a batch) before harvesting the cells for lipid extraction.

\subsection{Molecular characterization}

\subsubsection{DNA extraction and PCR amplification}

Yeast genomic DNA was extracted using a HIMEDIA yeast DNA extraction kit (HiPurA ${ }^{\mathrm{TM}} 96$ Yeast Genomic DNA Purification kit). DNA amplification was performed with GeneAmp PCR system (Applied Biosystems, USA). The PCR mixture was prepared by mixing $1.5 \mu \mathrm{L}$ of $15 \mathrm{mM} \mathrm{MgCl}$, $1.5 \mu \mathrm{L}$ 10XTaq buffer, $1.2 \mu \mathrm{L}$ of $2 \mathrm{mM}$ dNTPs, $0.2 \mu \mathrm{L} 1$ Unit Taq polymerase, $1 \mu \mathrm{L}$ of each forward and reverse primer (5 picomolar concentration) and nuclease-free water to obtain a final volume of $15 \mu \mathrm{L}$. To the reaction mixture, $1 \mu \mathrm{L}$ genomic DNA was added as the template. The sequences of the ITS primers used were as follows: ITS1 forward: 5'-TCCGTAGGTGAACCTGCGG-3' and ITS4 reverse: 5'-TCC TCCGCTTATTGATATGC-3'. PCR was run for 40 cycles, and the conditions used for the amplification of 185 rDNA gene were: initial denaturation $\left(94^{\circ} \mathrm{C}\right.$ for $\left.2 \mathrm{~min}\right)$, denaturation $\left(94{ }^{\circ} \mathrm{C}\right.$ for $\left.1 \mathrm{~min}\right)$, annealing $\left(45^{\circ} \mathrm{C}\right.$ for $\left.40 \mathrm{~s}\right)$, elongation 
( $72{ }^{\circ} \mathrm{C}$ for $2 \mathrm{~min}$ ) followed by a final elongation step $\left(72{ }^{\circ} \mathrm{C}\right.$ for $10 \mathrm{~min}$ ).

\subsubsection{DNA sequencing}

Following resolution in agarose gel, the $\mathrm{PCR}$ product was purified using gel extraction kit (Bangalore Genei) and sequenced. Sequencing reaction was performed using a PRISM BigDye Terminator v3.1Cycle sequencing kit. The DNA samples containing the extension products were added to Hi-Di formamide (Applied Biosystems, Foster City, CA). The mixture was incubated at $95^{\circ} \mathrm{C}$ for $5 \mathrm{~min}$, followed by 5 min on ice and then analyzed by ABI Prism3730XL DNA analyzer (Applied Biosystems, Foster City, CA).

\subsubsection{Nucleotide sequence analysis}

Consensus sequence of $18 \mathrm{~S}$ rRNA gene was generated from forward and reverse sequence data using aligner software. The $18 \mathrm{~S}$ rRNA gene sequence of the yeast strain $0 A 03$ was submitted to NCBI GenBank and was assigned the accession number KF650433. The 18S rRNA gene sequence obtained was used to carry out BLAST analysis [48]. Based on maximum identity score, the sequences of other yeast isolates and strains were selected and the respective sequences were retrieved from the online database. The retrieved sequences of the selected organisms were aligned using CLC Main Workbench and clustered using neighbor-joining method to generate the phylogenetic tree.

\subsection{Lipid extraction}

Total lipid was determined by the method of Bligh and Dyer [49].

\subsection{In situ transesterification}

In situ transesterification was carried out with modifications [50]. 1,1,3,3-Tetramethylguanidine (TMG) was used as the catalyst. In short, transesterification reactions were carried out with $100 \mathrm{mg}$ of lyophilized yeast biomass. The sample biomass was reacted with $2 \mathrm{ml}$ of $\mathrm{CH}_{3} \mathrm{OH}$ containing $25 \%(\mathrm{v} / \mathrm{v}) \mathrm{TMG}$ for $30 \mathrm{~min}$ at $60^{\circ} \mathrm{C}$. Following completion, the reaction was quenched by adding $\mathrm{CHCl}_{3}(1 \mathrm{~mL})$ whereby forming a single-phase solution with $\mathrm{CH}_{3} \mathrm{OH}$. Phase separation was achieved by washing the methanol-chloroform solution with $5 \mathrm{ml}$ distilled water. This was followed by centrifugation at $2000 \mathrm{rpm}$ for $2 \mathrm{~min}$. The upper phase was comprised of TMG and $\mathrm{CH}_{3} \mathrm{OH}$ with water, whereas FAME, TAG and other lipids partitioned with $\mathrm{CHCl}_{3}$ in the lower organic phase. The remnant biomass formed a layer at the boundary between two phases. The $\mathrm{CHCl}_{3}$ phase was removed by a syringe and collected in a $10-\mathrm{mL}$ centrifuge tube. The remnant biomass was twice washed with $2 \mathrm{~mL}$ of $\mathrm{CHCl}_{3}$ to recover residual FAMEs and lipids. The total $\mathrm{CHCl}_{3}$ volume was brought to $5 \mathrm{ml}$ and mixed by inversion following which $100 \mu \mathrm{l}$ aliquot was used for GC analysis.

\subsection{GC-FID analysis}

The fatty acid profile of Saccharomyces cerevisiae was determined by GC of the corresponding methyl ester on a TRACE ${ }^{\mathrm{TM}} 1300$ (Thermo Scientific) gas chromatograph equipped with FID detector and TRACE ${ }^{\text {TM }}$ TR-FAME GC column. The column temperature was held at $50^{\circ} \mathrm{C}$ for $2 \mathrm{~min}$, raised to $200{ }^{\circ} \mathrm{C}$ at $10^{\circ} \mathrm{C} / \mathrm{min}$, followed by $300^{\circ} \mathrm{C}$ at $5{ }^{\circ} \mathrm{C} /$ min and finally held for $10 \mathrm{~min}$ at the same temperature. Helium was used as the carrier gas at a flow rate of $1 \mathrm{ml} /$ $\mathrm{min}$. The identification of individual components was done by comparison of retention time with the standard FAME mix. The wt\% of the individual fatty acids was calculated based on the internal standard.

\subsection{Determination of fuel properties}

For comparison, the fuel properties of FAMEs (biodiesel) were determined using a set of empirical relations [51]. The following general expression is used to estimate the properties of biodiesel from the properties of individual FAMEs:

$f_{b}=\sum_{i=1}^{n} z_{i} \cdot f_{i}$

where $f$ is a function that represents any physical property (i.e., viscosity, density or calorific value), the subscripts b and $i$ refer to the biodiesel and the pure ith FAME, respectively), $z_{i}$ is the mass or mole fraction of the ith FAME. The function $f_{b}$ is replaced by the variables $\ln \eta_{i}, \rho_{i}$ and $\delta_{i}$ in order to specify the $\mathrm{CN}$, natural logarithm of kinematic viscosity, density and higher heating value (calorific value) of biodiesel, whereas the function $f_{i}$ is interchanged by the variables $\ln \eta_{i}, \rho_{i}$ and $\delta_{i}$ of the individual ith FAME [51].

The individual FAME properties were estimated using the following mathematical relations:

The kinematic viscosity expressed as a function of $M_{i}$ and $N$ is given as,

$\ln \eta_{i}=-12.503+2.496 \ln M_{i}-0.178 N$

where $\eta_{i}$ is the kinematic viscosity at $40^{\circ} \mathrm{C}$ of the ith FAME in $\mathrm{mm}^{2} / \mathrm{s}$.

The general expression used for the determining the density of saturated and unsaturated FAMEs is: 
$\rho_{i}=0.8463+\frac{4.9}{M_{i}}+0.0118 N$

where $\rho_{i}$ is the density at $20^{\circ} \mathrm{C}$ of the ith FAME in $\mathrm{g} / \mathrm{cm}^{3}$.

The calorific value of methyl esters can be calculated from:

$\delta_{i}=46.19-\frac{1794}{M_{i}}-0.21 \mathrm{~N}$

where $\delta_{i}$ is the calorific value of the $i$ th FAME in $\mathrm{MJ} / \mathrm{kg}$.

\subsection{Economics of yeast biofuel}

In the present investigation, economics of producing of yeast biofuel was estimated based on a previous study [6] on algal biomass.

The yeast de-oiled cake following lipid extraction was assumed as a feedstock for thermal/catalytic cracking. The quantity of yeast biomass ( $M$ tons), which is the energy equivalent of a barrel of crude petroleum, can be estimated as follows: for the biomass would be the same as the price of a barrel of crude petroleum; thus,

Acceptable price of biomass ( $\$ /$ ton) can be calculated as follows:

Acceptable price of biomass $=\frac{\text { Price of a barrel of petroleum }}{M}$

\section{Results and discussion}

\subsection{Isolation and molecular characterization}

The yeast strain under investigation was isolated from rice cakes (locally known as 'pitha') which are used as starter culture by the Ahom community of Assam, India. The rice cakes have been in use since centuries for the production of rice beer from a kind of sticky rice locally known as the 'bora rice.' Among all the isolated strains, the one which exhibited marked degree of ecological success (as evident from faster growth rate) was selected for the present investigation. Morphological characterization

$M=\frac{E_{\text {Petroleum }}}{y w E_{\text {biodiesel }}+(1-w)\left(E_{\text {bio-oil }} x_{\text {bio-oil }}+q E_{\text {syngas }} x_{\text {syngas }}+E_{\text {biochar }} x_{\text {biochar }}\right)}$

where $E_{\text {Petroleum }}(\sim 6100 \mathrm{MJ})$ is the energy content in the crude petroleum, $w$ is the oil content of the biomass in weight percentage and $y$ is the biodiesel yield from yeast biomass. $E_{\text {biodiesel, }}, E_{\text {bio-oil, }} E_{\text {syngas }}$ and $E_{\text {biochar }}$ are the energy contents of biodiesel, bio-oil, syngas and biochar, respectively. Similarly, $x_{\text {bio-oil }}, x_{\text {syngas }}$ and $x_{\text {biochar }}$ are the fractions of bio-oil, syngas and biochar, which are obtained as the products of cracking process and $q$ is $\left(\mathrm{m}^{3} /\right.$ ton) of syngas obtained from the cracking unit.

Assuming that the cost involved in converting a barrel of crude petroleum to various transport fuels is equivalent to converting $M$ tons of biomass to bioenergy, the maximum acceptable price that could be compensated and subsequent molecular analysis revealed the strain as S. cerevisiae. It is noteworthy to mention here within that these microorganisms have been traditionally used for fermentation processes; however, their potential with regard to biodiesel production has not been scientifically assessed properly.

Figure 1 shows the partial DNA sequence of the conserved region of $18 \mathrm{~S}$ rRNA gene of S. cerevisiae OA03. BLAST analysis (Table 1 ) revealed up to $96 \%$ homology of 18S rDNA sequence of strain 0A03 to 18S rDNA sequences of other known strains of $S$. cerevisiae. The sequence was deposited in the NCBI GenBank database and was assigned the GenBank accession No. KF650433.
Fig. 1 Partial DNA sequence of the conserved region of $18 \mathrm{~S}$ rRNA gene of S. cerevisiae $0 \mathrm{AO}$

AAAATTTTAATAATTTTGAAATGGATTTTTTTTGTTTTGGCAAGAGCATGAGAGCTTTTACTGGGCA
AGAAGACAAGAGATGGAGAGTCCAGCCGGGCCTGCGCTTAAGTGCGCGGTCTTGCTAGGCGTAA
GTTTCTTTCTTGCTATTCCAAACGGTGAGAGATTTCTGTGCTTTTGTTATAGGACAATTAAAACCGTT
TCAATACAACACACTGTGGAGTTTTCATATCTTTGCAACTTTTTCTTTGGGCATCAGCAATCGGGGCC
CAGAGGTAACAAACACAAACAATTTTATTTATTCATTAAATTTTTGTCAAAAAACAAGAATTTTCGTA
ACTGGAAATTTTAAAATATTAAAAACTTTCAACAACGGATCTCTGGTCTCGCATCGATGAAGAACGC
AGCGAAATGCGATACGTAATGTGAATTGCAGAATTCCGTGAATCATCGAATCTTTGAACGCACATTG
CGCCCCTTGGTATTCCAGGGGGCATGCCTGTTTGAGGTCTTTCCTTCTCAAACATTCTGTTTGGTAG
TGAGTGATACTCTTTGGAGTTAACTTGAAATTGCTGGCCTTTTCATTGGATGTTTTTTTTTTTCCAAA
GAGAGGTTTCTCTGCGTGCTGGAGGTAAATGAATTACGGTCGTTTTAGGTTTTCCCAACTGCGGCT
AATCTTTTTTTATACCGGAGCGTATTGAACCGTTATCGAATAAGAAGAGAGCGTTCTAGGCGACCAA
TGTTCTTAAAGTTTGACTTCATCAGTAGAAGTACCCGCTGACTTAGCATATCATAACGCGGA

AAAATTTTTAATAATTTTGAAATGGATTTTTTTTTGTTTTGGCAAGAGCATGAGAGCTTTTACTGGGCA AGAAGACAAGAGATGGAGAGTCCAGCCGGGCCTGCGCTTAAGTGCGCGGTCTTGCTAGGCGTAA GTTTCTTTCTTGCTATTCCAAACGGTGAGAGATTTCTGTGCTTTTGTTATAGGACAATTAAAACCGTT TCAATACAACACACTGTGGAGTTTTCATATCTTTGCAACTTTTTTCTTTGGGGCATCAGCAATCGGGGCC ACTGGAAATTTTAAAATATTAAAAACTTTCAACAACGGATCTCTGGTCTCGCATCGATGAAGAACGC AGCGAAATGCGATACGTAATGTGAATTGCAGAATTCCGTGAATCATCGAATCTTTGAACGCACATTG CGCCCCTTGGTATTCCAGGGGGCATGCCTGTTTGAGGTCTTTCCTTCTCAAACATTCTGTTTGGTAG TGAGTGATACTCTTTGGAGTTAACTTGAAATTGCTGGCCTTTTCATTGGATGTTTTTTTTTTTTCCAAA AATCTTTTTTTATACCGGAGCGTATTGAACCGTTATCGAATAAGAAGAGAGCGTTCTAGGCGACCAA TGTTCTTAAAGTTTGACTTCATCAGTAGAAGTACCCGCTGACTTAGCATATCATAACGCGGA 
Table 1 BLAST analysis

\begin{tabular}{|c|c|c|c|c|c|c|}
\hline Description & Max. score & Total score & $\begin{array}{l}\text { Query } \\
\text { cover } \\
(\%)\end{array}$ & $E$ value & Identity (\%) & Accession \\
\hline $\begin{array}{l}\text { Saccharomyces cerevisiae strain } 0 \mathrm{~A} 0318 \mathrm{~S} \text { ribosomal gene, partial } \\
\text { sequence }\end{array}$ & 1421 & 1421 & 100 & 0.0 & 99 & KF650433.1 \\
\hline $\begin{array}{l}\text { Saccharomyces cerevisiae isolate YN2 } 18 \mathrm{~S} \text { ribosomal gene, partial } \\
\text { sequence: internal transcribed spacer } 1.58 \mathrm{~S} \text { ribosomal RNA gene }\end{array}$ & 1288 & 1288 & 99 & 0.0 & 96 & KJ502661.1 \\
\hline $\begin{array}{l}\text { Saccharomyces cerevisiae strain W36 } 18 \text { S ribosomal gene, partial } \\
\text { sequence: internal transcribed spacer } 1.58 \text { S ribosomal RNA gene }\end{array}$ & 1286 & 1286 & 98 & 0.0 & 96 & DQ167471.1 \\
\hline $\begin{array}{l}\text { Saccharomyces cerevisiae strain } X 14-3185 \text { ribosomal gene, partial } \\
\text { sequence: internal transcribed spacer } 1.58 \text { S ribosomal RNA gene }\end{array}$ & 1284 & 1284 & 99 & 0.0 & 96 & JN837099.1 \\
\hline $\begin{array}{l}\text { Saccharomyces cerevisiae strain X68-2 } 18 \mathrm{~S} \text { ribosomal gene, partial } \\
\text { sequence: internal transcribed spacer } 1.58 \mathrm{~S} \text { ribosomal RNA gene }\end{array}$ & 1282 & 1282 & 99 & 0.0 & 96 & JN837100.1 \\
\hline $\begin{array}{l}\text { Saccharomyces cerevisiae strain P1 18S ribosomal gene, partial } \\
\text { sequence: internal transcribed spacer } 1.58 \mathrm{~S} \text { ribosomal RNA gene }\end{array}$ & 1280 & 1280 & 99 & 0.0 & 96 & KU131578.1 \\
\hline $\begin{array}{l}\text { Saccharomyces cerevisiae isolate YN3 } 18 \text { S ribosomal gene, partial } \\
\text { sequence: internal transcribed spacer } 1.58 \text { S ribosomal RNA gene }\end{array}$ & 1280 & 1280 & 99 & 0.0 & 96 & KJ502662.1 \\
\hline $\begin{array}{l}\text { Saccharomyces cerevisiae isolate AUS-LFB-MA-YC6 } 18 \mathrm{~S} \text { ribosomal } \\
\text { gene, partial sequence: internal transcribed spacer } 1.58 \mathrm{~S} \text { riboso- } \\
\text { mal RNA gene }\end{array}$ & 1280 & 1280 & 98 & 0.0 & 96 & JN093147.1 \\
\hline $\begin{array}{l}\text { Saccharomyces cerevisiae strain PMM08-412-AL isolate ISHAM-ITS ID } \\
\text { MITS2754 18S ribosomal gene, partial sequence: internal tran- } \\
\text { scribed spacer } 1.58 \text { S ribosomal RNA gene }\end{array}$ & 1279 & 1279 & 97 & 0.0 & 96 & KP132597.1 \\
\hline $\begin{array}{l}\text { Saccharomyces cerevisiae strain Sc20 18S ribosomal gene, partial } \\
\text { sequence: internal transcribed spacer } 1.58 \mathrm{~S} \text { ribosomal RNA gene }\end{array}$ & 1279 & 1279 & 97 & 0.0 & 96 & KC515374.1 \\
\hline $\begin{array}{l}\text { Saccharomyces cerevisiae strain Chicha } 0818 \mathrm{~S} \text { ribosomal gene, } \\
\text { partial sequence: internal transcribed spacer } 1.58 \mathrm{~S} \text { ribosomal RNA } \\
\text { gene }\end{array}$ & 1279 & 1279 & 99 & 0.0 & 95 & KC183729.1 \\
\hline
\end{tabular}

Additionally, the nucleotide sequences of other similar organisms from BLAST analysis were retrieved from the GenBank database. Their nucleotide sequences were aligned using CLC main workbench, and a tree was created based on neighbor-joining method which is shown in Fig. 2 along with the respective bootstrap values. The phylogenetic tree revealed the strain $0 \mathrm{A0} 3$ to be closely related to S. cerevisiae strain $\mathrm{X} 68-2$ and $\mathrm{SC} 20$ belonging to the same cluster with a high bootstrap value of 100 and 98 , respectively. A bootstrap value of $70 \%$ or higher indicates reliable groupings and shows the measure of phylogenetic accuracy and repeatability of the phylogenetic trees [52]. Thus, it is evident that the isolated yeast species, with a bootstrap value of 100 , is $S$ cerevisiae strain $0 \mathrm{~A} 03$.
Fig. 2 Phylogenetic relationship of S. cerevisiae $0 \mathrm{~A} 03$ and other closely related Saccharomyces species based on $18 \mathrm{~S}$ rDNA sequencing

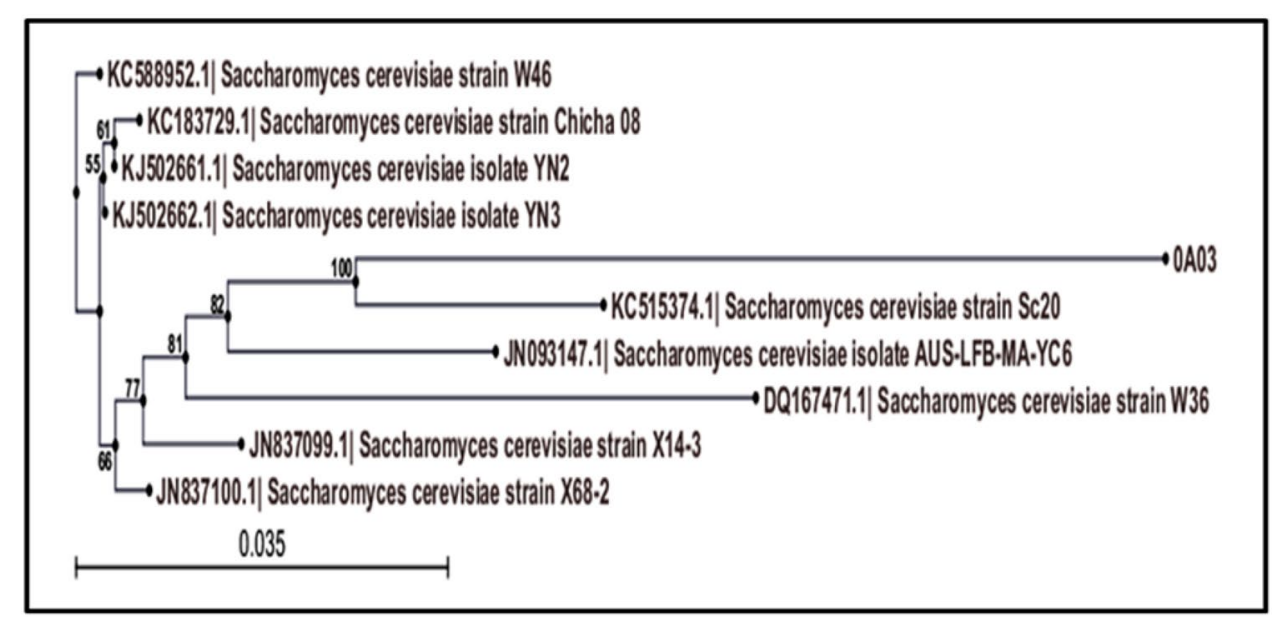




\subsection{Fatty acid analysis of S. cerevisiae $0 \mathrm{AO3}$}

Oil accumulation in yeasts has been known since many years. These oils, generally referred to as Single Cell Oils (SCOs), are triacylglycerols and can constitute up to $70 \%$ of the weight of the yeast cells [53]. The fatty acyl components of the triacylglycerols are the same as those that occur in plants such as soybean and rapeseed oil [53]. Fatty acid analysis in yeast is important not only from the biofuel standpoint, but also from the perspective of distinguishing between closely related yeast species both at the generic and at the species levels. Acceptable proportion of saturated and unsaturated fatty acids is crucial for investigating yeast as a biodiesel feedstock. Yeasts usually have an average lipid content ranging from 5 to $15 \% \mathrm{dw}$ [54], and S. cerevisiae has been reported to have a lipid content of 35-147 mg/g dw [55]. In this study, S. cerevisiae 0A03 had a lipid content of $12.8 \% \mathrm{dw}$. The fatty acids present in S. cerevisiae 0A03 (Table 2) were C12:0 (13.35\%), C16:1 (28.96\%), C16:0 (5.03), C18:2 (2.01), C18:1 isomer (18.13), C18:0 (1.76), C20:5 (2.01) and C23:0 (28.71), respectively. The fatty acids of $\mathrm{S}$. cerevisiae $0 \mathrm{~A} 03$ were similar to previous reports on oleaginous yeasts [53]. In addition, two additional longchain fatty acids, viz. C20:5 (eicosapentaenoic acid) and C23:0 (tricosylic acid), were present in S. cerevisiae 0A03. Halim et al. (2011) reported the lipid content for the dry biomass of microalgae Chlorococcum sp. as 7.1\% [56]. Biodiesel from the microalga Monoraphidium sp. is comprised of palmitic acid (C16:0), oleic acid (C18:1), linoleic acid (C18:2) and linolenic acid (C18:3), with palmitic acid (C16:0) and linoleic acid (C18:2) being the major fractions [57]. A comparison of the fatty acid composition of S. cerevisiae and microalgae is presented in Table 3. A representative gas chromatogram of the FAME mix is presented in Fig. 3.

Biodiesel from S. cerevisiae $0 \mathrm{A03}$ is expected to have poor oxidative stability owing to the presence of longchain unsaturated fatty acid, which may restrict its utilization. Biodiesel from highly unsaturated sources oxidizes more rapidly than conventional diesel, resulting in formation of insoluble sediments which interferes with engine performance [58]. One strategy to deal with the oxidative stability would be to extract the PUFA prior to biodiesel synthesis. Very-long-chain PUFA is well known for their

Table 2 Fatty acids of S. cerevisiae $0 \mathrm{A03}$

\begin{tabular}{lllc}
\hline SI nos. & Retention time & Fatty acid & wt (\%) \\
\hline 1 & 17.443 & C12:0 & 13.3501 \\
2 & 25.155 & C16:1 & 28.9673 \\
3 & 25.642 & C16:0 & 5.03778 \\
4 & 28.513 & C18:2 & 2.01511 \\
5 & 28.685 & C18:1 isomer & 18.136 \\
6 & 29.248 & C18:0 & 1.76322 \\
7 & 31.22 & C20:5 & 2.01511 \\
8 & 37.183 & C23:0 & 28.7154 \\
\hline
\end{tabular}

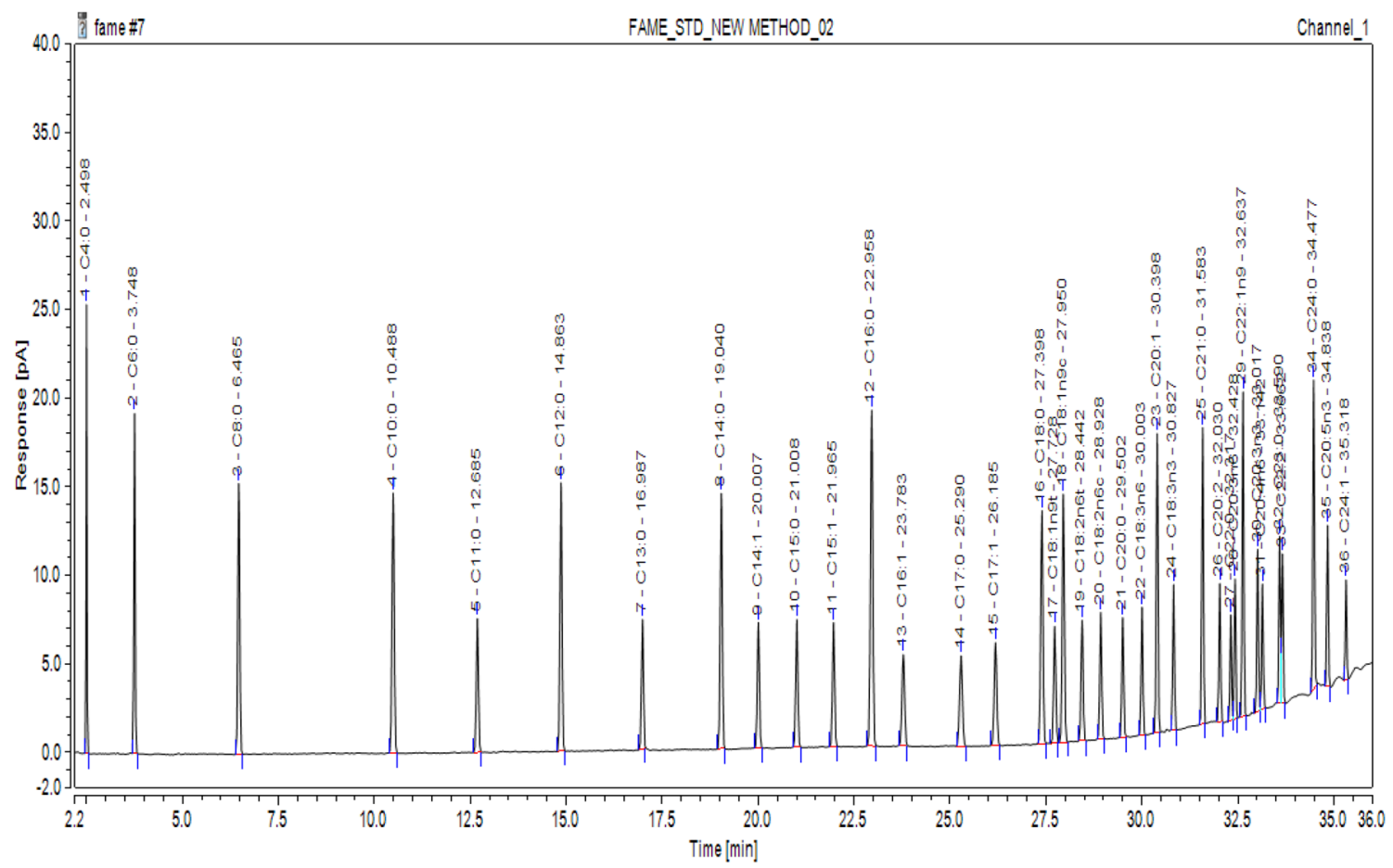

Fig. 3 Representative gas chromatogram of the FAME mix 
Table 3 Fatty acids profile of S. cerevisiae and microalgae Chlorococcum sp. and Monoraphidium sp

\begin{tabular}{llll}
\hline Fatty acid & S. cerevisiae wt (\%) & $\begin{array}{l}\text { Chlorococcum } \\
\text { sp. [56] wt (\%) }\end{array}$ & $\begin{array}{l}\text { Monoraphidium } \\
\text { sp. [57] wt (\%) }\end{array}$ \\
\hline C12:0 & 13.3501 & - & - \\
C16:1 & 28.9673 & $\sim 04$ & - \\
C16:0 & 5.03778 & $\sim 19$ & 32.83 \\
C18:3 & - & - & 19.31 \\
C18:2 & - & - & 29.85 \\
C18:1 & 2.01511 & $\sim 04$ & 18.01 \\
C18:1 isomer & 18.136 & $\sim 63$ & \\
C18:0 & 1.76322 & $\sim 03$ & - \\
C20:5 & 2.01511 & - & - \\
C23:0 & 28.7154 & - & - \\
\hline
\end{tabular}

Table 4 Fuel properties of S. cerevisiae $0 \mathrm{A03}$ biodiesel

\begin{tabular}{lll}
\hline Fuel properties & Yeast biodiesel & ASTM standard \\
\hline Density $\left(\mathrm{g} / \mathrm{cm}^{3}\right.$ at $\left.15^{\circ} \mathrm{C}\right)$ & 0.870 & $0.86-0.9$ \\
Viscosity $\left(\mathrm{mm}^{2} / \mathrm{s}\right.$ at $\left.40^{\circ} \mathrm{C}\right)$ & 5.797 & $3.5-5$ \\
Calorific value $(\mathrm{MJ} / \mathrm{kg})$ & 40.142 & - \\
Cetane number $(\mathrm{CN})$ & 71.58 & - \\
\hline
\end{tabular}

nutritional importance. PUFA has been reported to confer flexibility, fluidity and selective permeability properties to cellular membranes [59]. This is crucial for brain development, advantageous for the cardiovascular system and for other important pharmaceutical targets [59]. It is desirable that the extraction of pharmaceutical-grade PUFA should be coupled with biodiesel production from yeast to reduce the economics of feedstock utility. S. cerevisiae $0 \mathrm{~A} 03$ biodiesel is composed primarily of tricosylic acid (C23:0, $28.71 \%)$, palmitoleic acid (C16:1, 28.90\%) and oleic acid (C18:1, 18.13\%). High percentage of saturated fatty acids and monounsaturated fatty acids were also observed in the yeast strain. This may be considered optimal from a fuel quality standpoint because fuel polymerization during combustion would be substantially less than with PUFAderived fuel [11].

\subsection{Fuel properties of yeast biodiesel}

The fatty acid profile of the feedstock oil influences the biodiesel fuel properties. Calorific value, cetane numbers (CN), cold flow properties, oxidative stability, viscosity, etc., are some of the important fuel properties that are being influenced. Table 4 presents the fuel properties of the biodiesel as against ASTM specifications. In this study, we have only considered four fuel properties, viz. density, kinematic viscosity, calorific value and $\mathrm{CN}$. In general, the properties of biodiesel are quite similar to conventional petro-diesel. Density of the yeast biodiesel was $0.870 \mathrm{~g} /$ $\mathrm{cm}^{3}$, which was well within the ASTM range $(0.86-0.90 \mathrm{~g} /$ $\mathrm{cm}^{3}$ ). Conversely, yeast biodiesel exhibited a slightly higher kinematic viscosity $\left(5.797 \mathrm{~mm}^{2} / \mathrm{s}\right)$. Unlike the $\mathrm{CN}$, the kinematic viscosity increases with the number of carbon and decreases with the degree of unsaturation [60]. The presence of C23:0 (28.71\%) in yeast biodiesel can be attributed to the rise in kinematic viscosity of yeast biodiesel. This higher kinematic viscosity is likely to create engine problems such as engine deposits [61]. The use of biosurfactants may be helpful in reducing this high viscosity of the yeast biodiesel. Biosurfactants are much preferable in comparison with chemical surfactants in this respect, owing to their environmentally benign nature. The calorific value of yeast biodiesel was $40.142 \mathrm{MJ} / \mathrm{kg}$. In general, the calorific value of petro-diesel ranges from 39 to $41 \mathrm{MJ} / \mathrm{kg}$ [59]. The calorific values for yeast and microalgal biodiesel were in close proximity. A Chinese study reported microalgal Chlorella protothecoides biodiesel with calorific value of $41 \mathrm{MJ} / \mathrm{kg}$ [62]. CN is one of the most important properties of biodiesel fuel. $\mathrm{CN}$ has been extensively used to assess the ignition quality of fuels. The $\mathrm{CN}$ for yeast biodiesel was 71.58, which was much higher than that for conventional petro-diesel fuels. The $\mathrm{CN}$ of petro-diesel fuels generally fall within the range of 47 to 51 [63]. According to a previous study, this value for microalgal biodiesel ranges from 39 to 54 [64]. A CN value of 70 was previously reported for biodiesel from the microalga Spirulina platensis [65]. High CN in yeast biodiesel can be attributed to increase in saturated FAMEs content and its chain length [65]. Higher $\mathrm{CN}$ results in higher combustion efficiency, improved engine performance and cleaner emissions and can be recommended for use in the high-speed engine (speeds above $800 \mathrm{rpm}$ ) [65]. Conversely, fuels with low CN will cause difficulty in engine starting, generate higher noise and exhaust smoke [65].

\subsection{Economics of yeast biofuel}

Let us consider in Eq. (5), $\mathrm{y}=0.90, E_{\text {bio-oil }}=27,216 \mathrm{MJ} /$ ton, $E_{\text {syngas }}=15 \mathrm{MJ} / \mathrm{m}^{3}, E_{\text {biochar }}=27,216 \mathrm{MJ} /$ ton, $x_{\text {bio-oil }}=0.25$, $x_{\text {syngas }}=0.45, x_{\text {biochar }}=0.30$ and $q=1050 \mathrm{~m}^{3} /$ ton. From the experimental results, $E_{\text {biodiesel }}$ was obtained as $35,742 \mathrm{MJ} /$ ton. $E_{\text {Petroleum }}=6100 \mathrm{MJ}$. Accordingly, Eq. (5) becomes

$M=\frac{6100}{32167.8 w+22056.3(1-w)}$

The predictable price of yeast biofuel calculated on the basis of Eqs. (5-7) is shown in Fig. 4 for crude petroleum prices up to $\$ 1000 /$ barrel and for biomass with $20-80 \%$ oil content. With $\$ 100 /$ barrel of petroleum yeast biomass with an oil content of $80 \%$ needs 


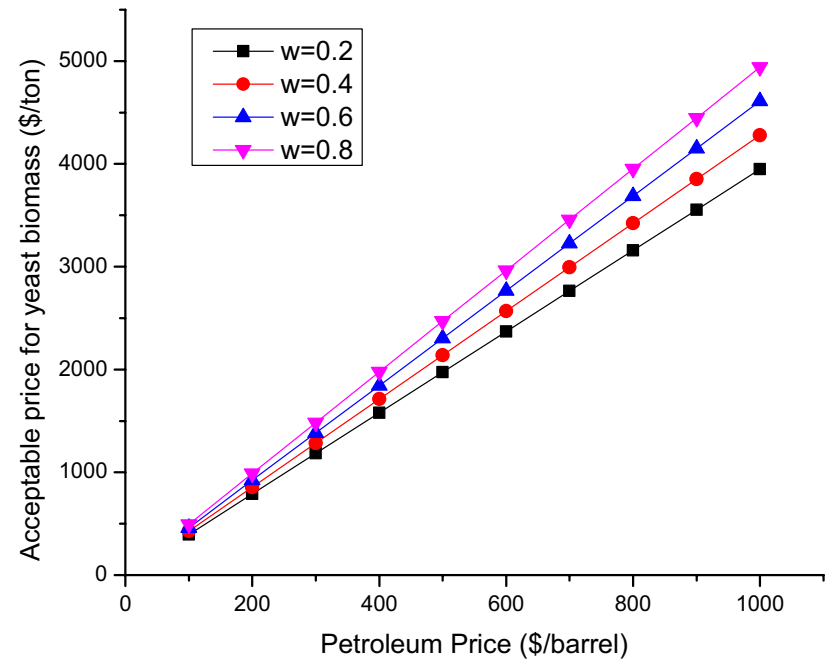

Fig. 4 Competitiveness of yeast biomass with petroleum prices

to be produced at $<\$ 495$ ton $^{-1}$ to be competitive with petroleum. Consequently, taking into account the yeast biomass production cost as $\$ 1500$ ton $^{-1}$, the price of producing yeast biomass needs to decline by a factor of $\sim 3$. Strain improvement in yeast (genetic and metabolic engineering-based approaches) coupled with advances in biomass conversion technologies and downstream processing can be instrumental in curbing down overall yeast biomass production cost.

Economic favorability is unlikely to make any sense if the focus is only on the final product (biodiesel here). A biorefinery model for yeast necessitates the use of low-cost substrates, co-production of high value-added products [66]. As such, the current investigation also takes into account possible income generation from biomass residues (yeast de-oiled cake) through theoretical approaches. Several biofuel research studies have focused on producing biodiesel from microorganisms such as microalgae. Similarly for yeasts, such a production scheme will definitely produce an enormous amount of de-oiled cake as a low-value biomass refuse. Material and energy recovery from these biomass refuses is undeniably a challenge for the forthcoming biorefineries. One viable option in this regard would be to couple the production of biodiesel with cracked biofuel products. This integrated approach would be much favorable in reducing the economics of feedstock usefulness besides favoring the need for greater reliance of mankind on a bio-based economy. With greater research capacities, the conversion technologies involved in biofuel production from yeast may prove economically competitive with petroleum refining. However, yeast biofuel research is still at its infantile stage, and concept to commercialization of these biofuels can only be appraised through critical analysis of the process economics of large-scale production.
Considering the fatty acid profile, fuel properties and theoretical approach, the yeast strain S. cerevisiae $0 \mathrm{~A} 03$ necessitates further research for sensible biodiesel production. The study also warrants superior research competence (strain improvement, oxidative stability, cold flow properties, exhaust emissions, viscosity reduction, lubricity, etc.) for a better comprehensive understanding.

\section{Conclusion}

Yeasts have always captivated the attention of the scientific community as model organisms for fermentation processes (bioalcohol production). However, in this study we have specifically emphasized on an entirely new perspective, viz. biodiesel production from yeast. Our findings advocate that the yeast strain S. cerevisiae $0 \mathrm{A0} 03$ exhibits several interesting features for bioenergy research. Elevated proportions of saturated fatty acids and monounsaturated fatty acids in the yeast strain may be considered optimal from a fuel quality standpoint. High energy content $(40.142 \mathrm{MJ} / \mathrm{kg})$ and high CN (71.58) of yeast biodiesel are indicative of improved engine performance, higher combustion efficiency and cleaner emissions. Furthermore, our findings necessitate the need for coupling biodiesel production with cracking to improve biofuel process economics. Theoretical studies suggest that yeast biomass conversion technologies are likely to prove economically competitive with petroleum refining. We conclude that microorganisms like yeasts with untapped biological diversity should be harnessed for bioenergy-biorefinerybased applications in lines parallel with microalgae. However, this work warrants greater research capacities such as life-cycle assessment (LCA) for a better comprehensive understanding of yeast biorefinery concept.

Acknowledgements The authors acknowledge the DBT, Government of India-sponsored BIF Centre of Nagaland University for nucleotide sequence analysis. The authors are thankful to Dr. L. J. Konwar for GC-FID analysis.

\section{Compliance with ethical standards}

Conflict of interest The authors declare that they have no competing interests.

\section{References}

1. Wang C, Chen L, Rakesh B, Qin Y, Lv R (2012) Technologies for extracting lipids from oleaginous microorganisms for biodiesel production. Front Energy 6:266-274

2. Patel A, Arora N, Mehtani J, Pruthi V, Pruthi PA (2017) Assessment of fuel properties on the basis of fatty acid profiles of 
oleaginous yeast for potential biodiesel production. Renew Sustain Energy Rev 77:604-616

3. Bora P, Konwar LJ, Boro J, Phukan MM, Deka D, Konwar BK (2014) Hybrid biofuels from non-edible oils: a comparative standpoint with corresponding biodiesel. Appl Energy 135:450-460

4. Santamauro F, Whiffin FM, Scott RJ, Chuck CJ (2014) Low-cost lipid production by an oleaginous yeast cultured in non-sterile conditions using model waste resources. Biotechnol Biofuel 7(34):1-11

5. Chiaramonti D, Prussi M, Buffi M, Rizzo AM, Pari L (2017) Review and experimental study on pyrolysis and hydrothermal liquefaction of microalgae for biofuel production. Appl Energy 185(2):963-972

6. Chisti $Y$ (2008) Biodiesel from microalgae beats bioethanol. Trends Biotechnol 26:126-131

7. Katiyar R, Gurjar BR, Biswas S, Pruthi V, Kumar N, Kumar P (2017) Microalgae: an emerging source of energy based bio-products and a solution for environmental issues. Renew Sustain Energy Rev 72:1083-1093

8. Spolaore P, Joannis-Cassan C, Duran E, Isambert A (2006) Commercial applications of microalgae. J Biosci Bioeng 101:87-96

9. Czyrnek-Delêtre MM, Rocca S, Agostini A, Giuntoli J, Murphy JD (2017) Life cycle assessment of seaweed biomethane, generated from seaweed sourced from integrated multi-trophic aquaculture in temperate oceanic climates. Appl Energy 196:34-50

10. Jha P, Schmidt S (2017) Reappraisal of chemical interference in anaerobic digestion processes. Renew Sustain Energy Rev 75:954-971

11. Sheehan J, Dunahay TG, Benemann JR, Roessler PG, Weissman JC (1998) A look back at the U.S. Department of Energy's Aquatic Species Program: biodiesel from algae. National Renewable Energy Laboratory, Golden. ReportNREL/TP-580-24190. http:// www.nrel.gov/docs/legosti/fy98/24190.pdf. Accessed 12 March 32012

12. Miao $\mathrm{X}, \mathrm{Wu} \mathrm{Q}$ (2006) Biodiesel production from heterotrophic microalgal oil. Bioresour Technol 97:841-846

13. Chisti Y (2007) Biodiesel from microalgae. Biotechnol Adv 25:294-306

14. Vicente G, Carrero A, Rodríguez R, Peso GL (2017) Heterogeneous-catalysed direct transformation of microalga biomass into biodiesel-grade FAMEs. Fuel 200:590-598

15. Zhang K, Sun B, She X, Zhao F, Cao Y, Pen D, Lu J (2014) Lipid production and composition of fatty acids in Chlorella vulagaris culture using different methods: photoautotrophic, heterotrophic, and pure and mixed conditions. Ann Microbiol 64:1239-1246

16. Arvindnarayan S, Prabhu KKS, Shobana S, Pasupathy A, Dharmaraja J, Kumar G (2017) Potential assessment of micro algal lipids: a renewable source of energy. J Energy Inst 90(3):431-440

17. Gnansounou E, Raman JK (2016) Life cycle assessment of algae biodiesel and its co-products. Appl Energy 161:300-308

18. Sivaramakrishnan R, Incharoensakdi A (2017) Direct transesterification of Botryococcus sp. catalysed by immobilized lipase: ultrasound treatment can reduce reaction time with high yield of methyl ester. Fuel 191:363-370

19. Akkerman I, Janssen M, Rocha J, Wijffels RH (2002) Photo biological hydrogen production: photochemical efficiency and bioreactor design. Int J Hydrog Energy 27:195-208

20. Ortigueira J, Alves L, Gouveia L, Moura P (2015) Third generation biohydrogen production by Clostridium butyricum and adapted mixed cultures from Scenedesmus obliquus microalga biomass. Fuel 153:128-134

21. Sekoai PT, Awosusi AA, Yoro KO, Singo M, Oloye O, Ayeni AO, Bodunrin M, Daramola MO (2018) Microbial cell immobilization in biohydrogen production: a short overview. Crit Rev Biotechnol 38(2):157-171
22. Sekoai PT, Yoro KO, Daramola MO (2016) Batch fermentative biohydrogen production process using immobilized anaerobic sludge from organic solid waste. Environments 3(38):1-10

23. Elliott DC (2016) Review of recent reports on process technology for thermochemical conversion of whole algae to liquid fuels. Algal Res 13:255-263

24. Miao X, Wu Q (2004) High yield bio-oil production from fast pyrolysis by metabolic controlling of Chlorella protothecoides. J Biotechnol 110:85-93

25. Pan P, Hu C, Yang W, Li Y, Dong L, Zhu L, Tong D, Qing R, Fan $Y$ (2010) The direct pyrolysis and catalytic pyrolysis of Nannochloropsis sp. residue for renewable bio-oils. Bioresour Technol 101:4593-4599

26. Harun R, Jason WSY, Cherrington T, Danquah MK (2011) Exploring alkaline pre-treatment of microalgal for bioethanol production. Appl Energy 88(10):3464-3467

27. Harun R, Danquah M (2011) Influence of acid pretreatment on microalgal biomass for bioethanol production. Process Biochem 46(1):304-309

28. Sharma YC, Singh B, Korstad J (2011) A critical review on recent methods used for economically viable and eco-friendly development of microalgae as a potential feedstock for synthesis of biodiesel. Green Chem 13:2993-3006

29. Suali E, Sarbatly R (2012) Conversion of microalgae to biofuel. Renew Sustain Energy Rev 16:4316-4342

30. Kings AJ, Raj RE, Miriam LRM, Visvanathan MA (2017) Cultivation, extraction and optimization of biodiesel production from potential microalgae Euglena sanguinea using eco-friendly natural catalyst. Energy Convers Manag 141:224-235

31. Markou G, Georgakakis D (2011) Cultivation of filamentous cyanobacteria (blue-green algae) in agro-industrial wastes and wastewaters: a review. Appl Energy 88:3389-3401

32. Chiaramonti D, Maniatis K, Tredici MR, Verdelho V, Yan J (2015) Life cycle assessment of algae biofuels: needs and challenges. Appl Energy 154:1049-1051

33. Muthunarayanan $V$, Bosco GE, Chandran T, Duraisamy T, Muniraj S, Sewsynker-Sukai Y, Moodley P, Gumbi Z (2018) Biologically renewable resources of energy: potentials, progress and barriers. In: Sivasankar V, Mylsamy P, Omine K (eds) Microbial fuel cell technology for bioelectricity. Springer, Cham

34. Yamada R, Kashihara T, Ogino H (2017) Improvement of lipid production by the oleaginous yeast Rhodosporidium toruloides through UV mutagenesis. World J Microbiol Biotechnol 33(5):99

35. Saenge C, Cheirsilp B, Suksaroge TT, Bourtoom T (2011) Potential use of oleaginous red yeast Rhodotorula glutinis for the bioconversion of crude glycerol from biodiesel plant to lipids and carotenoids. Process Biochem 46:210-218

36. Cheirsilp B, Kitcha S, Torpee S (2012) Co-culture of an oleaginous yeast Rhodotorula glutinis and a microalga Chlorella vulgaris for biomass and lipid production using pure and crude glycerol as a sole carbon source. Ann Microbiol 62:987-993

37. Xue F, Zhang X, Luo H, Tan T (2006) A new method for preparing raw material for biodiesel production. Process Biochem 41:1699-1702

38. Malisorn C, Suntornsuk W (2008) Optimization of $\beta$-carotene production by Rhodotorula glutinis DM 28 in fermented radish brine. Bioresour Technol 99:2281-2287

39. Angerbauer C, Siebenhofer M, Mittelbach M, Guebitz GM (2008) Conversion of sewage sludge into lipids by Lipomyces starkeyi for biodiesel production. Bioresour Technol 99:3051-3056

40. Feofilova EP, Sergeeva YE, Ivashechkin AA (2010) Biodiesel-fuel: content, production, producers, contemporary biotechnology (Review). Appl Biochem Microbiol 46:369-378

41. Papanikolaou S, Aggelis G (2010) Yarrowia lipolytica: a model microorganism used for the production of tailor-made lipids. Eur J Lipid Sci Technol 112:639-654 
42. Wild R, Patil S, Popovic M, Zappi M, Dufreche S, Bajpai R (2010) Lipids from Lipomyces starkeyi. Food Technol Biotechnol 48:329-335

43. Thiru M, Sankh S, Rangaswamy V (2011) Process for biodiesel production from Cryptococcus curvatus. Bioresour Technol 102:10436-10440

44. Wu S, Zhao X, Shen H, Wang Q, Zhao ZK (2011) Microbial lipid production by Rhodosporidium toruloides under sulfate-limited conditions. Bioresour Technol 102:1803-1807

45. Li Q, Du W, Liu D (2008) Perspectives of microbial oils for biodiesel production. Appl Microbiol Biotechnol 80:749-756

46. Li YH, Liu B, Zhao ZB, Bai FW (2006) Optimization of culture conditions for lipid production by Rhodosporidium toruloides. Chin J Biotechnol 22:650-656

47. Yahmed NB, Jmel MA, Alaya MB, Bouallagui $H$, Marzouki MN, Smaali I (2016) A biorefinery concept using the green macroalgae Chaetomorpha linum for the coproduction of bioethanol and biogas. Energy Convers Manag 119:257-265

48. Altschul SF, Gish W, Miller W, Myers EW, Lipman DJ (1990) Basic local alignment search tool. J Mol Biol 215:403-410

49. Bligh EJ, Dyer WJ (1959) A rapid method of total lipid extraction and purification. Can J Biochem Physiol Pharmacol 37:911-917

50. Wahlen BD, Willis RM, Seefeldt LC (2011) Biodiesel production by simultaneous extraction and conversion of total lipids from microalgae, cyanobacteria, and wild mixed-cultures. Bioresour Technol 102:2724-2730

51. Ramírez-Verduzco LF, Rodríguez-Rodríguez JE, Jaramillo-Jacob AR (2012) Predicting cetane number, kinematic viscosity, density and higher heating value of biodiesel from its fatty acid methyl ester composition. Fuel 91:102-111

52. Hillis DM, Bull JJ (1993) An empirical test of bootstrapping as a method for assessing confidence in phylogenetic analyses. Syst Biol 42:182-192

53. Ratledge C, Cohen Z (2008) Microbial and algal oils: do they have a future for biodiesel or as commodity oils? Lipid Technol 20:155-160
54. Rattray JB, Schibeci A, Kidby DK (1975) Lipids of yeasts. Bacteriol Rev 39:197-231

55. Rattray JBM (1988) Yeasts. In: Ratledge C, Wilkinson SG (eds) Microbial lipids. Academic, London, pp 555-697

56. Halim R, Gladman B, Danquah MK, Webley PA (2011) Oil extraction from microalgae for biodiesel production. Bioresour Technol 102(1):178-185

57. Chen J-J, Lee Y-R (2018) Optimization of the transesterification reaction of microalgal Monoraphidium sp. Renew Energy 129(8):717-723

58. Deng X, Li Y, Fei X (2009) Microalgae: a promising feedstock for biodiesel. Afr J Microbiol Res 3:1008-1014

59. Demirbas A (2008) Biodiesel: a realistic fuel alternative for diesel engines. Springer, London

60. Knothe G, Krahl J, Gerpen JV (eds) (2015) The biodiesel handbook. AOCS Press, Urbana

61. Knothe G, Steidley KR (2005) Kinematic viscosity of biodiesel fuel components and related compounds. Influence of compound structure and comparison to petro diesel fuel components. Fuel 84:1059-1065

62. Xu H, Miao X, Wu Q (2006) High quality biodiesel production from a microalga Chlorella protothecoides by heterotrophic growth in fermenter. J Biotechnol 126:499-507

63. Knothe G (2006) Analyzing biodiesel: standards and other methods. JAOCS 83:823-833

64. Stansell GR, Gray VM, Sym SD (2012) Microalgal fatty acid composition: implications for biodiesel quality. J Appl Phycol 24:791-801

65. Mostafa SSM, El-Gendy NS (2017) Evaluation of fuel properties for microalgae Spirulina platensis bio-diesel and its blends with Egyptian petro-diesel. Arabian J Chem 10(2):S2040-S2050

66. Kumar RR, Dhanarajan G, Bhaumik M, Chopra J, Sen R (2017) Performance evaluation of a yeast biorefinery as a sustainable model for co-production of biomass, bioemulsifier, lipid, biodiesel and animal feed components using inexpensive raw materials. Sustain Energy Fuels 1:923-931 